\title{
PHARMACOGNOSTICAL EVALUATION, IN VITRO ANTIOXIDANT EFFECTS OF SYZYGIUM CUMINI LINN. SEED EXTRACT, AND THE POTENTIAL ROLE OF THIS EXTRACT AS HYPOGLYCEMIC AGENT IN ALLOXAN-INDUCED DIABETIC RATS
}

\author{
RANU BISWAS ${ }^{1 *}$, KALYAN KUMAR SEN ${ }^{2}$ \\ ${ }^{1}$ Department of Pharmaceutics, BCDA College of Pharmacy and Technology, Kolkata, West Bengal, India. ${ }^{2}$ Department of Pharmaceutics, \\ Gupta College of Technological Sciences, Asansol, West Bengal, India. Email: ranubiswas2008@gmail.com
}

Received: 17 May 2018, Revised and Accepted: 11 June 2018

\begin{abstract}
Objective: Diabetes, the "third killer" of mankind, is now a global burden affecting nearly $10 \%$ of the population. The present study aimed at pharmacognostical evaluation of Syzygium cumini seed powder, phytochemical profiling, total phenolic, and flavonoid content determination and to ascertain its antioxidant activity and hypoglycemic potential in alloxan-induced diabetic rats.

Methods: Pharmacognostical and physicochemical parameters of the seed powder were determined by using standard methods as per Ayurvedic Pharmacopoeia of India (API). In vitro antioxidant activity was determined by 1, 1-diphenyl-2-picrylhydrazyl (DPPH) radical scavenging activity. Ethanolic extract of Syzygium cumini seed at a dose of $200 \mathrm{mg} / \mathrm{kg}$ and $400 \mathrm{mg} / \mathrm{kg}$ body weight (bw) were given orally in alloxan-induced $(150 \mathrm{mg} / \mathrm{kg}$, i.p) diabetic rats daily for three weeks.

Results: physicochemical parameters complied with the API standards. Phytochemical profiling revealed that the extract contains phenolic compounds, flavonoids, glycosides, alkaloids, tannins, and saponins. The extract is rich in phenolic compounds which were $177.33 \mathrm{mg}$ gallic acid equivalent/g (GAE/g dry weight) and showed significant percentage inhibition compared to standard ascorbic acid. The extract reduced the fasting blood sugar (FBS) level by 46.67-52.67\% which is very close to the standard drug glibenclamide (reduced FBS by $65.58 \%$ ). It also improved the bw by $18.20-20.41 \%$ after extract treatment where the standard drug increased the bw by $22.95 \%$ of the diabetic rats.
\end{abstract}

Conclusion: In conclusion, Syzygium cumini seed extract is rich in phenolic compounds. Results suggested that the extract possesses significant radical (DPPH) scavenging activity and FBS lowering potential in alloxan-induced diabetic rats.

Keywords: Syzygium cumini, Antioxidant activity, Hypoglycemic, Alloxan-induced diabetic rats, Total phenolics, Total flavonoids.

(C) 2018 The Authors. Published by Innovare Academic Sciences Pvt Ltd. This is an open access article under the CC BY license (http://creativecommons. org/licenses/by/4. 0/) DOI: http://dx.doi.org/10.22159/ajpcr.2018.v11i10.27363

\section{INTRODUCTION}

Plants have provided mankind with herbal remedies for many diseases for many centuries and even today. Recently, great attention has been devoted to the use of natural compounds. India is one of the Nations blessed with a rich heritage of traditional medicinal systems [1]. When the man is increasing complexities by adding free radicals, nature is helping him by supplying immense natural antioxidants which inactivate the free radicals and stop unwanted oxidation in the body which involve the free radicals formation [2]. The use of herbal medicine due to toxicity and side effects of allopathic medicines has led to a sudden increase in the number of herbal drug manufacturers. The proper authentication of herbal raw materials is critically important to the safety and efficacy of herbal medicines. World Health Organization (WHO) has emphasized the need to ensure quality control of medicinal plant products using modern techniques and by applying suitable parameters and standards [3]. Diabetes, the third "killer" of mankind after cardiovascular disease and cancer, is affecting nearly $10 \%$ of the world population [4]. Diabetes mellitus (DM), one of the most common endocrine-metabolic disorders is characterized by abnormally high blood sugar levels resulting from the body's inability to produce or properly use insulin. Type 2 is characterized by a progressive decline in insulin action (insulin resistance, followed by the inability of pancreatic $\beta$ cells to compensate for insulin resistance). In type $2 \mathrm{DM}$, the function of $\beta$ cells becomes impaired due to insulin resistance leading to deterioration in glucose homeostasis and subsequent development of impaired glucose tolerance [5]. In diabetes, hyperglycemia generates reactive oxygen species (ROS) which, in turn, cause lipid peroxidation and membrane damage and thus, causes secondary complications in DM such as kidney, eye, blood vessel, and nerve damage [6].

Oral hypoglycemic agents ameliorate the underlying metabolic disorders, related to inadequate insulin secretion, insulin resistance, and augmented hepatic gluconeogenesis. However, these agents have limited efficacy and sometimes produced severe side effects such as weight gain, hypoglycemia, liver injury, channel disturbances, and cardiopathy. Therefore, there is a need to develop effective, safe and cheap drugs for diabetes management. Such effective, safe and cheap drugs could be obtained using medicinal plants which have been used by humans to prevent or cure diseases including diabetes since the dawn of civilization [7]. The use of natural products as antioxidants in the management of DM has gained importance throughout the world. There has been increasing research focused on natural foods and medicinal plants and their phytoconstituents due to their well-known abilities to scavenge free radicals. The WHO has also recommended and encouraged the use of natural products for the management of diabetes and in oxidative stress conditions. Natural antioxidants such as flavonoids and polyphenols are believed to possess antioxidant properties due to their reducing and chelating capabilities. Natural antioxidants can preserve $\beta$-cell function by inhibiting the peroxidation chain reaction and prevent diabetes-induced ROS formation [8].

Most of the plant parts of Syzygium cumini (L), family Myrtaceae (commonly known as Jamun) are documented in the traditional 
systems of medicine in India as a hypoglycemic in the management of diabetes. Therefore, the objective of the present study was to perform the pharmacognostical and physicochemical evaluation of S. cumini seed powder, phytochemical profiling of ethanolic extract of $S$. cumini seed, determination of total phenolic and flavonoid content and to ascertain it's in vitro antioxidant activity and hypoglycemic potential in alloxan-induced diabetic rats.

\section{METHODS}

\section{Chemicals}

Glibenclamide (Cadila Pharmaceuticals Ltd., Ahmedabad, India), Gallic acid, Ascorbic acid (Loba Chemie Pvt Ltd. Mumbai, India), 1, 1-diphenyl2-picrylhydrazyl (DPPH) (SRL Pvt. Ltd., Mumbai, India), Quercetin (Herbo Nutra, New Delhi, India), and Alloxan monohydrate (Sd Fine Chemicals, Mumbai, India), all other chemicals and reagents are of analytical grade.

\section{Instruments}

Ultraviolet (UV)-visible spectrophotometer (Thermo Spectronic UV-1, Great Britain), pH meter (Digital pH Meter 335, Systronics, Ahmedabad, India), Metlar Toledo (AB 204-S, Switzerland), Rotary vacuum evaporator (Rolex, India), Centrifuge machine (Remi Equipments Pvt. Ltd., Mumbai, India), and glucometer (Accu-chek active blood glucose monitoring system) were used.

\section{Plant material}

S. cumini seed powder was obtained (Vyas Pharmaceuticals, a GMP certified unit, Indore, MP, India).

\section{Morphological evaluation of seed powder}

Morphological characteristics of the powdered drug such as color, odor, texture, and taste were studied.

\section{Physicochemical evaluation}

Moisture content, $\mathrm{pH}$, foreign matter, total ash, acid insoluble ash, water soluble ash, water, ethanol, and chloroform-soluble extractive values were determined according to the WHO guidelines on quality control methods for medicinal plant material and as per the Ayurvedic Pharmacopoeia of India (API) $[9,10]$.

\section{Preparation of extract}

The $S$. cumini seed powder was extracted with ethanol: water (70:30) at room temperature by maceration for 14 days. The extract was then filtered and concentrated by a rotary vacuum evaporator at a temperature of $40^{\circ} \mathrm{C}$. It was then kept in the refrigerator in an airtight container for further studies.

\section{Preliminary phytochemical profiling}

The extract was screened for the presence of phenolic compounds, flavonoids, tannins, saponins, alkaloids, glycosides, steroids, proteins and amino acids, carbohydrates, resins, and triterpenoids using various qualitative tests. All tests were performed as per the standard procedures [11].

\section{Determination of total phenolic content (TPC)}

The TPC of $S$. cumini seed extract was determined using Folin-Ciocalteu reagent method. The intense blue color was developed after incubation. The absorbance was measured at $760 \mathrm{~nm}$ using UV-visible spectrophotometer taking gallic acid as standard $(10-60 \mu \mathrm{g} / \mathrm{mL}$ in water). The TPC was expressed as mg of gallic acid equivalent (GAE)/g of dw [12-14].

\section{Determination of total flavonoid content (TFC)}

Total flavonoid was determined using the aluminum chloride colorimetric method on the formation of a complex flavonoid aluminum. The developed yellow color indicated the presence of flavonoid. The absorbance was measured at $420 \mathrm{~nm}$ using a UV-visible spectrophotometer. The TFC was calculated using a calibration curve for quercetin $(10-60 \mu \mathrm{g} / \mathrm{mL}$ in ethanol) as the standard. The result was expressed as $\mathrm{mg}$ of quercetin equivalent $(\mathrm{QE}) / \mathrm{g}$ dry extract $[12,15]$.
Free radical (DPPH) scavenging activity

The stable DPPH radical was used to assess the free radical scavenging potential of the crude ethanolic extract of S. cumini which, in turn, determines the in vitro antioxidant activity. The absorbance was measured at $517 \mathrm{~nm}$ using a UV-visible spectrophotometer. Ascorbic acid (50-300 $\mu \mathrm{g} / \mathrm{mL}$ in water) was used as reference standard. DPPH solution and distilled water served as control and blank [16-18].

The free radical-scavenging activity was calculated using the following formula:

$$
\% \text { inhibition } \equiv \frac{\text { Ao- }-\mathrm{At}}{\text { Ao }} \times 100
$$

Where,

Ao $=$ Absorbance of the control

At $=$ Absorbance of the sample

\section{Reducing power ability}

The reducing power of the extract was investigated by the $\mathrm{Fe}^{+3}-$ $\mathrm{Fe}^{+2}$ transformation in the presence of the fractions. The $\mathrm{Fe}^{+2}$ can be monitored by measuring the formation of Perl's Prussian blue at $700 \mathrm{~nm}$. Ascorbic acid was used as the standard [19,20].

\section{Antidiabetic activity study}

Acute toxicity study

The acute oral toxicity study was performed as per the Organization for Economic Co-operation and Development (OECD) 423 (acute oral toxicity - Acute toxic class method, 2001) guidelines. The limit test was employed as the test material is non-toxic as per information gathered. For the test, six female Wister albino rats (100-150 g) were selected and divided into two each containing three. Normally, females are used. This is because literature surveys of conventional $L_{50}$ tests show that, although there is little difference in sensitivity between the sexes, in those cases where differences are observed females are generally slightly more sensitive. The rats were kept for at least 5 days in caged for laboratory acclimatization before use and fasted (food, but the water was not withheld) overnight ( $12 \mathrm{~h}$ ). A limit test at one dose level of $2000 \mathrm{mg} / \mathrm{kg}$ body weight (bw) was given to one group. The animals were observed continuously for the first $4 \mathrm{~h}$ (at least once during the first $30 \mathrm{~min}$ ) and for the next 6,24, and $48 \mathrm{~h}$ after extract administration and daily thereafter, for a total of 14 days. If no death will occur, a limit test at one dose level of $5000 \mathrm{mg} / \mathrm{kg}$ was given to another group on the $5^{\text {th }}$ day. Neurological and behavioral changes were observed for any signs of acute toxicity and recorded. All mortality within a period of testing the extract was also noted. If test substance-related mortality is produced, further testing at the next lower level may need to be carried out [21].

\section{Experimental animals}

Wistar albino rats were randomly bred in the Institutional Animal House. The animals were maintained under controlled room temperature $\left(22 \pm 2^{\circ} \mathrm{C}\right)$ and humidity $(55 \pm 5 \%)$ with $12: 12 \mathrm{~h}$ light and dark cycle. All the animals were provided with commercially available rat normal pellet diet and water ad libitum. The guidelines of the Committee for the Purpose of Control and Supervision of Experiments on Animals of the Goverment of India were followed, and prior permission and clearance were granted from the Institutional Animal Ethics Committee (No. - GCTS/IAEC/2014Jan/02) for conducting the animal experimental studies [5].

\section{Induction of diabetes}

Wistar albino rats of either sex weighing 100-150 g were selected for the study. Diabetes was induced in $12 \mathrm{~h}$ fasted rats by a single intraperitoneal injection of $150 \mathrm{mg} / \mathrm{kg}$ bw of freshly prepared alloxan monohydrate in distilled water. After alloxan injection rats were given $10 \% \mathrm{w} / \mathrm{v}$ glucose solution in feeding bottles for the next $24 \mathrm{~h}$ in their cages to prevent hypoglycemia. After $72 \mathrm{~h}$ rats with fasting blood glucose levels $>200 \mathrm{mg} / \mathrm{dL}$ were selected and used for the study $[6,15,22]$. 


\section{Treatment protocol}

The rats were divided into 5 groups, each containing 6 animals. The extract of $S$. cumini seed was given as a suspension in distilled water at a dose of $1 \mathrm{~mL} / \mathrm{kg}$ to different groups of animals [6,15,22].

- Group 1: Negative control (normal rats) received distilled water

- Group 2: Diabetic control received distilled water

- Group 3: Positive control received glibenclamide (10 mg/kg, p.o)

- Group 4: Diabetic rats received extract (200 mg/kg, p.o)

- Group 5: Diabetic rats received extract (400 mg/kg, p.o)

All were administered by oral gavage. The blood glucose levels and the weight of the rats were estimated at $0,7^{\text {th }}, 14^{\text {th }}$, and $21^{\text {st }}$ days with the drug and extract being administered daily for 21 days from the day of induction. Blood samples were drawn from the tip of the tail, and blood glucose level was measured using the glucometer.

\section{Statistical analysis}

All the experiments were carried out in triplicates. The values are represented as a mean \pm standard deviation (SD). Results were analyzed using one-way analysis of variance where $\mathrm{p}<0.05$ took as statistically significant value.

\section{RESULTS}

Morphological evaluation of seed powder

The seed powder is brownish colored with an aromatic odor, bitter tasted, and coarse textured.

\section{Physico-chemical evaluation}

The results of physico-chemical studies are expressed in Table 1.

Table 1: Summary of results: physico-chemical studies of the seed powder

\begin{tabular}{cc}
\hline Parameters & Results \\
\hline $\mathrm{pH}$ & 4.8 \\
Moisture content & $11.5 \% \mathrm{w} / \mathrm{w}$ \\
Foreign matter & $\mathrm{Nil}$ \\
Total ash & $3.32 \%$ \\
Acid-insoluble ash & $0.29 \%$ \\
Water-soluble ash & $1.54 \%$ \\
Alcohol soluble extractives & $87.1 \%$ \\
Water soluble extractives & $94.2 \%$ \\
Chloroform-soluble extractives & $90.95 \%$ \\
\hline
\end{tabular}

The experiments were performed in triplicate, and the data are represented as the mean value.

Preliminary phytochemical profiling

The phytoconstituents present in the extract are given in Table 2.

Table 2: Phytoconstituents of ethanolic extract of Syzygium cumini seed

\begin{tabular}{cc}
\hline Phytoconstituents & Ethanolic extract \\
\hline Phenols & + \\
Flavonoids & + \\
Alkaloids & + \\
Glycosides & + \\
Tannins & + \\
Saponins & + \\
Triterpenoids & + \\
Steroids & - \\
Proteins and amino acids & - \\
Resins & + \\
Glycosides & + \\
\hline
\end{tabular}

+: Present, -: Absent. S. cumini: Syzygium cumini
The standard curve of gallic acid

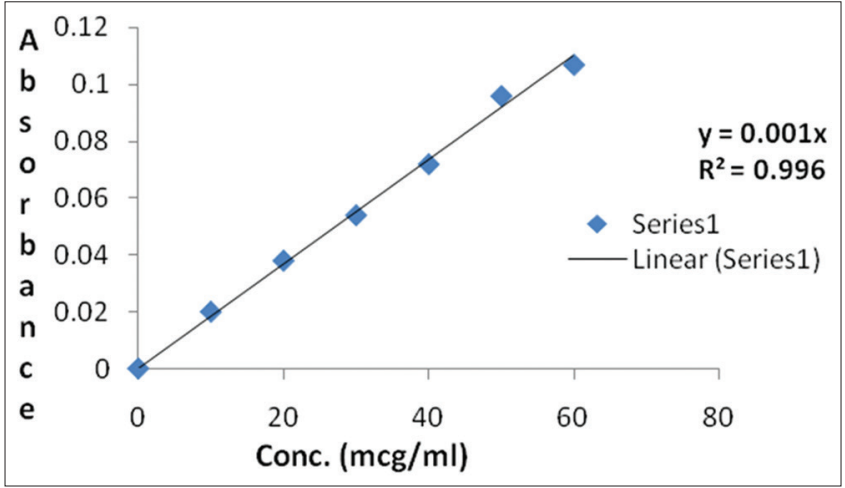

Fig. 1: Standard curve of gallic acid. Results are expressed as the mean value $(n=3)$

The standard curve of quercetin

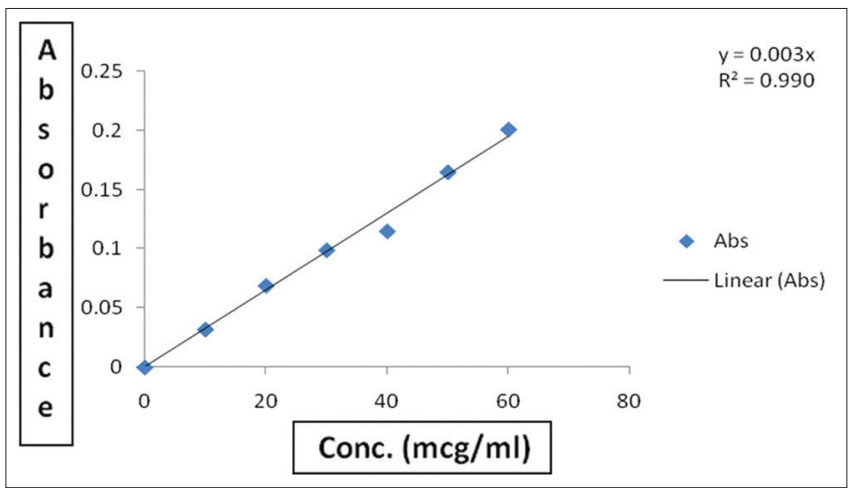

Fig. 2: Standard curve of quercetin. Results are expressed as the mean value $(n=3)$

TPC

The TPC of the extract was found to be $177.33 \pm 1.15 \mathrm{mg}$ of GAE/g of dry extract determined by Folin-Ciocalteu reagent method (Value is given as mean $\pm S D$, where $n=3$ ).

TFC

The TFC of the extract was found to be $86.33 \pm 1.52 \mathrm{mg}$ of QE/g of dry extract determined by the aluminum chloride colorimetric method (Value is given as mean $\pm S D$, where $n=3$ )

In vitro antioxidant study

Table 3 shows (DPPH radical scavenging activity). Table 4 shows (Reducing power ability).

\section{Acute toxicity studies (OECD 423)}

No mortality and no signs of toxicity were found at the dose of $2000 \mathrm{mg} / \mathrm{kg}$ and $5000 \mathrm{mg} / \mathrm{kg}$ bw. Therefore, it might be considered that hydroalcoholic extract of the seeds of S. cumini was safe to use below $5000 \mathrm{mg} / \mathrm{kg}$ bw. The extract was safely administered at a dose of $200 \mathrm{mg}$ and $400 \mathrm{mg}$ per $\mathrm{kg}$ bw to the alloxan-induced diabetic rats.

\section{Antidiabetic activity in alloxan-induced diabetic rats}

Table 5 shows (Changes in blood glucose level (mg/dL) in groups of normal and alloxan-induced diabetic rats $(n=6)$ ). Table 6 shows (Changes in body weight (g) in groups of normal and alloxan-induced diabetic rats $(n=6)$ ).

\section{DISCUSSION}

Although hyphenated analytical techniques are available, still pharmacognostical and physicochemical parameters study is more 
reliable to identify and evaluate herbal drugs [23]. Physicochemical parameters are very much helpful for judging the quality as well as purity of drugs [24]. S. cumini seed powder complied all the physicochemical standards as per the API and WHO guidelines for quality control methods for medicinal plant materials. Preliminary qualitative phytochemical analysis revealed the presence of various phytoconstituents (Table 2) which are reported to have many biological and therapeutic properties [25].

Plant phenolics, as hydrogen donating free radical scavengers, have received considerable attention as they are wide-spread plant secondary metabolites and also known as sources of potential natural antioxidants. They act both as radical scavengers and metal chelators $[26,27]$. TPC in the $S$. cumini seed extract was estimated by

Table 3: DPPH radical scavenging activity

\begin{tabular}{ccc}
\hline Conc. $(\mathrm{mcg} / \mathrm{mL})$ & \multicolumn{2}{c}{$\%$ of inhibition } \\
\cline { 2 - 3 } & $\begin{array}{c}\text { Ascorbic } \\
\text { acid }\end{array}$ & Extract \\
\hline 50 & $77.58 \pm 0.92$ & $45.41 \pm 1.00$ \\
75 & $87.79 \pm 0.74$ & $59.73 \pm 0.79$ \\
100 & $90.77 \pm 0.89$ & $67.39 \pm 0.52$ \\
150 & $91.60 \pm 1.32$ & $71.3 \pm 0.91$ \\
200 & $92.51 \pm 0.91$ & $75.67 \pm 0.88$ \\
250 & $95.46 \pm 0.53$ & $81.78 \pm 0.81$ \\
300 & $97.59 \pm 0.62$ & $86.42 \pm 1.07$ \\
\hline
\end{tabular}

Values are given as mean $\pm \mathrm{SD}$, where $\mathrm{n}=3$

Table 4: Reducing power ability

\begin{tabular}{ccc}
\hline Conc. $(\mathbf{m c g} / \mathbf{m L})$ & \multicolumn{2}{c}{ Absorbance at $\mathbf{7 0 0} \mathbf{~ n m}$} \\
\cline { 2 - 3 } & Ascorbic acid & Extract \\
\hline 50 & $0.325 \pm 0.01$ & $0.145 \pm 0.02$ \\
75 & $0.648 \pm 0.04$ & $0.358 \pm 0.03$ \\
100 & $0.751 \pm 0.04$ & $0.529 \pm 0.02$ \\
150 & $0.963 \pm 0.03$ & $0.797 \pm 0.04$ \\
200 & $1.197 \pm 0.08$ & $0.867 \pm 0.02$ \\
250 & $1.341 \pm 0.03$ & $0.938 \pm 0.05$ \\
300 & $1.593 \pm 0.06$ & $1.003 \pm 0.03$ \\
\hline
\end{tabular}

Values are given as mean \pm SD, where $n=3$
Folin-Ciocalteu reagent method which is simple, fast, convenient, and most importantly reproducible. The findings confirm that the extract is rich in phenolic contents $(177.33 \pm 1.15 \mathrm{mg} \mathrm{GAE} / \mathrm{g} \mathrm{dw})$.

Flavonoids also act through scavenging and chelating process. Flavonoids, which contain hydroxyl groups, are responsible for the antioxidant effect of the plant [28]. They are effective scavengers of most oxidizing molecules including singlet oxygen and various free radicals implicated in several diseases [29]. High flavonoid contents present in the extract, i.e. $86.33 \pm 1.52 \mathrm{mg} \mathrm{QE} / \mathrm{g} \mathrm{dw}$.

Free radical scavenging test is relatively straightforward to perform in vitro antioxidant activity. Stable DPPH radical scavenging method is a rapid, simple, inexpensive, reproducible, and sensitive way to survey the antioxidant activity of a specific compound or plant extracts in comparison to other models. In the presence of a hydrogen donating polyphenols in the extract, purple colored stable DPPH is reduced to yellow colored non-radical form DPPH-H (diphenylpicrylhydrazine) in a concentration dependent manner. The antioxidant effect is proportional to the disappearance of the purple color of DPPH in test samples [30-32]. The findings were represented in Table 3 as percentage inhibition, and the extract showed a fair scavenging activity lower than that of ascorbic acid (standard).

The reducing ability of the extract depends on the presence of reductant which exerts antioxidant action based on breaking the free radical chain by donating hydrogen atom. The reducer causes the conversion of $\mathrm{Fe}^{+3}$ / ferricyanide complex to $\mathrm{Fe}^{+2}$ form which is measured by the formation of Perl's Prussian blue at $700 \mathrm{~nm}$ [33]. The reducing power of extract was compared with ascorbic acid as standards. All the samples showed significant reducing power capacity in a concentration-dependent manner, but less than standard. The maximum reduction was observed at the concentration of $300 \mu \mathrm{g} / \mathrm{mL}$. The absorbance for extract was 1.003 and 1.593 for the standard. From the results obtained in this study, it is suggested that the ethanolic extract potentially donates the electron to reactive free radicals to convert them into more stable nonreactive form and terminates the free radical chain reaction [34].

Impaired carbohydrate, fat, and protein metabolism are associated with DM, which are of vital public importance as physiological complications associated with it [35]. The underlying causes of hyperglycemia in DM are overproduction and decreased utilization of glucose by the tissue. Most of the diabetic complications are mediated through oxidative

Table 5: Changes in blood glucose level $(\mathrm{mg} / \mathrm{dL})$ in groups of normal and alloxan-induced diabetic rats $(\mathrm{n}=6)$

\begin{tabular}{|c|c|c|c|c|c|}
\hline \multirow[t]{2}{*}{ Groups } & \multirow{2}{*}{$\begin{array}{c}\text { Pre-treatment } \\
\text { Day } 0\end{array}$} & \multicolumn{3}{|c|}{ Post-treatment } & \multirow[t]{2}{*}{ \% Reduction } \\
\hline & & Day 7 & Day 14 & Day 21 & \\
\hline Normal control & $84.73 \pm 3.32$ & $86.05 \pm 2.73$ & $86.21 \pm 2.68$ & $87.13 \pm 4.79$ & - \\
\hline Standard drug-treated & $286.07 \pm 4.33$ & $190.41 \pm 4.20^{*}$ & $126.52 \pm 4.28^{*}$ & $98.45 \pm 3.50^{*}$ & 65.58 \\
\hline Extract treated $200 \mathrm{mg} / \mathrm{kg}$ & $221.05 \pm 3.05$ & $200.85 \pm 2.83^{*}$ & $190.70 \pm 4.62 *$ & $117.87 \pm 3.54^{*}$ & 46.67 \\
\hline Extract treated $400 \mathrm{mg} / \mathrm{kg}$ & $236.24 \pm 2.65$ & $205.13 \pm 3.5^{*}$ & $178.81 \pm 3.99 *$ & $111.80 \pm 2.16^{*}$ & 52.67 \\
\hline
\end{tabular}

Values are given as mean $\pm \mathrm{SD}(\mathrm{n}=6)$ statistical significance was evaluated by one-way analysis of variance (ANOVA) at * $p<0.05$. Diabetic control was compared to normal control and experimental groups were compared to diabetic control group

Table 6: Changes in body weight $(\mathrm{g})$ in groups of normal and alloxan-induced diabetic rats $(\mathrm{n}=6)$

\begin{tabular}{|c|c|c|c|c|c|}
\hline \multirow[t]{2}{*}{ Groups } & \multirow[t]{2}{*}{ Before alloxan administration } & \multirow{2}{*}{$\begin{array}{c}\text { Pre-treatment } \\
\text { Day } 0\end{array}$} & \multicolumn{3}{|c|}{ Post-treatment } \\
\hline & & & Day 7 & Day 14 & Day 21 \\
\hline Normal control & $125.33 \pm 2.16$ & $125.66 \pm 1.80$ & $126.25 \pm 1.08$ & $127.25 \pm 1.75$ & $126.25 \pm 3.76$ \\
\hline Diabetic control & $121.25 \pm 1.12$ & $98.25 \pm 1.83^{*}$ & $88.5 \pm 1.44^{*}$ & $85.08 \pm 2.39^{*}$ & $78.83 \pm 3.2^{*}$ \\
\hline Standard drug-treated & $125 \pm 3.17$ & $93.66 \pm 1.53^{*}$ & $97.25 \pm 1.63^{*}$ & $102.08 \pm 1.80^{*}$ & $115.16 \pm 1.94 *$ \\
\hline Extract treated $200 \mathrm{mg} / \mathrm{kg}$ & $130.58 \pm 2.95$ & $91.5 \pm 2.02 *$ & $94.16 \pm 1.36^{*}$ & $97.08 \pm 3.36^{*}$ & $108.16 \pm 2.13^{*}$ \\
\hline Extract treated $400 \mathrm{mg} / \mathrm{kg}$ & $128.5 \pm 1.78$ & $92.66 \pm 3.17^{*}$ & $99 \pm 2.04^{*}$ & $101.5 \pm 2.81^{*}$ & $111.58 \pm 1.98 *$ \\
\hline
\end{tabular}

Values are given as mean $\pm \mathrm{SD}(\mathrm{n}=6)$ statistical significance was evaluated by one-way analysis of variance (ANOVA) at * $p<0.05$. Diabetic control was compared to normal control, and experimental groups were compared to diabetic control group 
stress. The oxidative stress and resultant tissue damage are important components in the pathogenesis of diabetic complications. Diabetes is associated with increased formation of free radicals and decreases in antioxidant potential. The increase in oxygen free radicals in diabetes could be due to increase in blood glucose levels, which on autooxidation generates free radicals [36]. The ROS and related oxidative stress are the root cause of developing insulin resistance, impaired $\beta$-cell function, and type-2 DM. Insulin resistance, which is the reduced response of target tissues such as skeletal muscle, liver, and adipocytes to insulin, plays a major role in the pathogenesis of type II diabetes. Skeletal muscle is the predominant site of insulin-mediated glucose uptake in the postprandial state. Normal glucose homeostasis depends on a well-balanced interaction between tissue sensitivity to insulin and insulin secretion [37]. To combat the diabetic complications, wide varieties of synthetic oral hypoglycemic agents are available. However, due to their undesirable side effects, there is a need to search for safe and effective molecules from nature. Therefore, in the present study, the hypoglycemic effect of $S$. cumini seed extract was investigated in alloxan-induced diabetic Wistar rats in comparison with the standard antidiabetic drug, glibenclamide $(10 \mathrm{mg} / \mathrm{kg}$ bw). The preliminary studies (acute toxicity study) revealed the non-toxic nature of the extract on normal rats. Alloxan has been widely used to induce diabetes in a wide variety of animals which causes $\beta$-cell cytotoxicity. In this study, the difference has been observed in initial and final FBS level and bw of different treated groups and significant elevation in blood glucose level in the diabetic control group at the end of 21-day study period $[8,38]$. The significant decrease in FBS level was observed after continuous treatment with extract for 21 days. The extract reduced the glucose level by $46.67 \%$ at $200 \mathrm{mg} / \mathrm{kg}$ bw and $52.67 \%$ at $400 \mathrm{mg} / \mathrm{kg}$ bw which is very close to the standard drug glibenclamide $(65.58 \%$ reduction). The extract treated group showed significant improvement in bw in comparison to diabetic control and glibenclamide treated group which is due to controlling muscle wasting (protein loss), i.e. - the reversal of gluconeogenesis. Glibenclamide which has been used for many years to treat diabetes stimulates insulin secretion from $\beta$-cell. The possible mechanism of hypoglycemic effect of $S$. cumini seed may be by potentiation of insulin effect $[4,6]$.

\section{CONCLUSION}

The outcomes of this study support the traditional use of $S$. cumini as potential therapeutic agents to treat various diseases mainly diabetes. Based on the results obtained, it has been concluded that the ethanolic extract of the seeds of $S$. cumini contains secondary metabolites which are associated with important biological activities. The extract is rich in phenols and flavonoids. It possesses strong antioxidant and blood glucose lowering potentials.

\section{ACKNOWLEDGMENT}

The author extends her warmest appreciation to her research adviser, Dr. Kalyan Kumar Sen, Principal, Gupta College of Technological Sciences, Asansol, WB, India, for his invaluable support for the completion of this research.

\section{AUTHOR'S CONTRIBUTIONS}

Ranu Biswas conducted the experiment and prepared the manuscript. Dr. Kalyan Kumar Sen supervised the work and helped in manuscript preparation and correction.

\section{CONFLICTS OF INTEREST}

The authors declare that there are no conflicts of interest.

\section{REFERENCES}

1. Jadhav M, Kamble S, Kadam V. Herbal medicine: Syzygium cumini: A review. J Pharm Res 2009;2:1212-9.

2. Garima Z, Amla B. In vitro and in vivo determination of phenolic contents and antioxidant activity of desert plants of Apocynaceae family. Asian J Pharm Clin Res 2012;5 Suppl 1:75-83.
3. Chitnis K, Palekar S, Koppar D, Mestry D. Evaluation of Syzygium cumini Linn. Seed formulations available in the market using spectrophotometric and chromatographic techniques. Int J Pharm Sci Res 2012;3:556-60.

4. Kumar A, Ilavarasan R, Jayachandran T, Deecaraman M, Aravindan P, Padmanabhan $\mathrm{N}$, et al. The Anti-diabetic activity of Syzygium cumini and its isolated compound against streptozotocin-induced diabetic rats. J Med Plants Res 2008;2:246-9.

5. Farswan M, Mazumder P, Parcha V. Modulatory effect of an isolated compound from Syzygium cumini seeds on biochemical parameters of diabetes in rats. Int J Green Pharm 2009;18:128-33.

6. Patel D, Kumar R, Prasad S, Sairam K, Hemalatha S. Antidiabetic and in vitro antioxidant potential of Hybanthus enneaspermus (Linn) F. Muell in streptozotocin- induced diabetic rats. Asian Pac J Trop Biomed 2011;1:316-22.

7. Sharma AK, Gupta R. Anti-Hyperglycemic activity of aqueous extracts of some medicinal plants on wistar rats. J Diabetes Metab 2017;8:1-7.

8. Arya A, Nyamathulla S, Noordin MI, Mohd MA. Antioxidant and hypoglycemic activities of leaf extracts of three popular Terminalia species. E J Chem 2012;9:883-92.

9. WHO. Quality Control Methods for Medicinal Plant material. Geneva: Organization Mondiale De La Sante; 1992. p. 8-26.

10. Government of India, Ministry of Health and Family Welfare. Ayurvedic Pharmacopoeioa of India. Part-II (Formulations), Vol-II, $1^{\text {st }}$ ed. Delhi: The Controller of Publications; 2008. p. 40-2.

11. Prabakaran K, Shanmugavel G. Antidiabetic activity and phytochemical constituents of Syzygium cumini seeds in Puducherry region, South India. Int J Pharmacogn Phytochem Res 2017;9:985-9.

12. Mbaebie BO, Edeoga HO, Afolayan A. Phytochemical analysis and antioxidants activities of aqueous stem bark extract of Schotia latifolia Jacq. Asian Pac J Trop Biomed 2012;2:118-24.

13. Kamtekar S, Keer V, Patil V. Estimation of phenolic content, flavonoid content, antioxidant and alpha-amylase inhibitory activity of marketed polyherbal formulation. J Appl Pharm Sci 2014;4:61-5.

14. Farhan H, Rammal H, Hijazi A, Hamad H, Daher A, Reda M, et al. In vitro antioxidant activity of ethanolic and aqueous extracts from crude Malva parviflora L. grown in Lebanon. Asian J Pharm Clin Res 2012;5 Suppl 3:234-8.

15. Maryglen F, Gargantiel, Mafel C, Ysrael. Antioxidant activity and hypoglycemic potential of Antidesma ghaesembilla Gaertn (Phyllantaceae). Int J Sci Tech Res 2014;3:422-31.

16. Bencheikh D, Khennouf S, Bouaziz A, Baghiani A, Dahamna S, Amira S, et al. Antioxidant and antidiabetic activities of the methanolic extract of Olea europaea L. leaves in Streptozotocin-induced diabetes in rats. Int J Pharmacogn Phytochem Res 2016;8:1347-57.

17. Venkateshwarlu E, Reddy RA, Goverdhan P, Rani KS, Reddy GJ. In vitro and in vivo antioxidant activity of methanolic extract of Solena amplexicaulis (Whole Plant). Int J Pharm Biol Sci 2011;1:522-33.

18. Sahu RK, Kar M, Routray R. DPPH free radical scavenging activity of some leafy vegetables used by Tribals of Odisha, India. J Med Plants Studies 2013;1: 21-7.

19. Jain S, Bhatia G, Barik R, Kumar P, Jain A, Dixit VK. Antidiabetic activity of Paspalum scrobiculatum Linn. in alloxan-induced diabetic rats. J Ethnopharmacol 2010;127:325-8.

20. Olugbami OJ, Gbadegesin MA, Odunola O. In vitro free radical scavenging and antioxidant properties of ethanol extract of Terminalia glaucescens. Pharmacogn Res 2015;7:49-56.

21. OECD 423. OECD Guideline for Testing of Chemicals. Acute Oral Toxicity-Acute Toxic Class Method; 2001.

22. Hossain MD, Sarwar MS, Dewan SMR, Hossain MS, Shahid-UdDaula AFM, Islam MS. Investigation of total phenolic content and antioxidant activities of Azadirachta indica roots. Avicenna J Phytomed 2014;4:97-102.

23. Khandelwal KR. Practical Pharmacognosy, Techniques, and Experiments. $17^{\text {th }}$ ed. New Delhi: Nirali Prakashan; 2007.

24. Kokate CK. Practical Pharmacognosy. $12^{\text {th }}$ ed. New Delhi: Vallabh Prakashan; 2008.

25. Senguttuvan J, Paulsamy S, Karthika K. Phytochemical analysis and evaluation of leaf and root parts of the medicinal herb, Hypochaeris radicata $\mathrm{L}$. for in vitro antioxidant activities. Asian Pac J Trop Biomed 2014;4:S359-67.

26. Lopez-Velez M, Martinez-Martinez F, Del Valle-Ribes C. The study of phenolic compounds as natural antioxidants in wine. Crit Rev Food Sci Nutr 2003;43:233-44.

27. Olorunjuwon J, Michael A, Gbadegesin, Odunola OA. In vitro free radical scavenging and antioxidant properties of ethanol extract of 
Terminalia glaucescens. Pharmacogn Res 2015;7:49-56.

28. Eshwarappa RSB, Iyer RS, Subbaramaiah SR, Richard SA, Dhananjaya BL. Antioxidant activity of Syzygium cumini leaf gall extracts. Bio Impacts 2014;4:101-7.

29. Jebitta SR, Allwin SJ. Antioxidant activity, total phenol, flavonoid and anthocyanin contents of Jamun (Syzygium cumini) pulp powder. Asian J Pharm Clin Res 2016;9 Suppl 2:361-3.

30. Russo D, Valentão P, Andrade PB, Fernandez EC, Milella L. Evaluation of antioxidant, antidiabetic and anticholinesterase activities of Smallanthus sonchifolius Landraces and correlation with their phytochemical profiles. Int J Mol Sci 2015;16:17696-718

31. Jimenez-Escrig A, Jimenez-Jimenez I, Sanchez-Moreno C, SauraCalixto F. Evaluation of free radical scavenging of dietary carotenoids by the stable radical 2,2-diphenyl-1-picrylhydrazyl. J Sci Food Agric 2000;80:1686-90.

32. Banerjee A, Maji B, Mukherjee S, Chaudhuri K, Seal T. In vitro antidiabetic and antioxidant activities of ethanol extract of Tinospora sinensis. Int J Curr Pharm Res 2017;9 Suppl 2:42-7.

33. Banerjee J, Narendhirakannan RT. Phytochemical analysis, antibacterial, in vitro antioxidant and cytotoxic activities of ethanolic extract of Syzygium cumini (L.) seed extract. Int J Pharm Sci Res 2011;2:1799-806.

34. Kumar T, Jain V. Appraisal of total phenol, flavonoid contents, and antioxidant potential of folkloric Lannea coromandelica using in vitro and in vivo assays. Scientifica (Cairo) 2015;2015:203679.

35. Nahid S, Majumder K, Rahman Z, Islam S, Rashid MH, Kerr PG. Cardio and hepatoprotective potential of methanolic extract of Syzygium cumini (L.) Skeels seeds: A diabetic rat model study. Asian Pac J Trop Biomed 2017;7Suppl 2:126-33

36. Kavitha S, Sivaraj R, Ravi D. Antidiabetic activity of Asystasia gangetica (L.) T. anderson flower extract in streptozotosin induced diabetic rats. Int J Pharm Pharm Sci 2016;8 Suppl 8:79-84.

37. Jose D, Aleykutty N. A, Jyoti H. Effect of combination of two plant extracts on diabetes mellitus. Int J Pharm Pharm Sci 2018;10 Suppl 4:49-52.

38. Sharma U, Sahu RK, Roy A, Golwala DK.In vivo antidiabetic and antioxidant potential of Stephania hernandifolia in Streptozotocininduced-diabetic rats. J Young Pharm 2010;2 Suppl 3:255-60. 